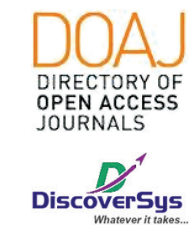

Published by DiscoverSys

\title{
Pemberian ekstrak kulit buah anggur (Vitis vinifera L.) mampu menurunkan kadar malondialdehid (MDA) plasma pada tikus dengan diet tinggi kolesterol
}

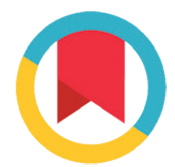

CrossMark

\author{
Etik Nurhidayati, ${ }^{1 *}$ Ni Made Linawati, ${ }^{2}$ I Wayan Sugiritama ${ }^{2}$
}

\section{ABSTRACT}

Introduction: High cholesterol levels will cause disease, one of which is cardiovascular disorders or diseases. Based on WHO data in 2012 there were 17.5 million deaths in the world due to cardiovascular disease. Coronary heart occupies the highest position at $42 \%$ where one of the most common risk factors is dyslipidemia. This research aimed to evaluate the effect of grape skin extract on plasma MDA level.

Methods: This study is an experimental study with a post-test only control group research design. Thirty male Wistar rats aged 2-3 months with a body weight of around 200 grams and healthy, classified into 4 treatment groups and a control group with a high cholesterol diet and administration of different dosages of grape skin extract, dose of $100 \mathrm{mg} / 175 \mathrm{gbw}$ (gram body weight), $250 \mathrm{mg} / 175 \mathrm{gbw}$, and $500 \mathrm{mg} / 175 \mathrm{gbw}$. All blood samples were taken on day 30 and an MDA test was performed. Kruskal Wallis test was performed to analyze the correlation.

Results: The test results obtained with $p<0.05$ in the group of rats given grape skin extract at a dose of $100 \mathrm{mg} / 175 \mathrm{gbw}$, $250 \mathrm{mg} / 175 \mathrm{gbw}$, and $500 \mathrm{mg} / 175 \mathrm{gbw}$, thus showing significantly lower MDA levels compared with control group.

Conclusion: Administration of grape skin extract to rats given a high cholesterol diet may reduce plasma MDA levels.

Keywords: grape skin (Vitis vinifera L.), anthocyanin, cholesterol, malondialdehyde (MDA)

Cite This Article: Nurhidayati, E., Linawati, N.M., Sugiritama, I.W. 2020. Pemberian ekstrak kulit buah anggur (Vitis vinifera L.) mampu menurunkan kadar malondialdehid (MDA) plasma pada tikus dengan diet tinggi kolesterol. Intisari Sains Medis 11(2): 638-642. D0l: 10.15562/ ism.v11i2.671

\section{ABSTRAK}

Latar belakang: Kolesterol yang tinggi di dalam darah akan mengakibatkan berbagai masalah kesehatan, salah satunya adalah gangguan atau penyakit kardiovaskular. Data tahun 2012 terdapat 17,5 juta kematian di dunia karena masalah kardiovaskular. Jantung koroner menduduki posisi tertinggi yaitu $42 \%$ dimana salah satu faktor risiko terseringnya adalah dislipidemia. Mengetahui dampak pemberian kulit buah anggur terhadap MDA plasma tikus adalah sasaran penelitian ini.

Metode: Sebuah penelitian eksperimental menggunakan metode

1Program Studi Sarjana Kedokteran dan Profesi Dokter, Fakultas Kedokteran Universitas Udayana, Denpasar, Bali, Indonesia ${ }^{2}$ Departemen Histologi, Fakultas Kedokteran Universitas Udayana, Denpasar, Bali, Indonesia

*korespondensi: Etik Nurhidayati, Program Studi Sarjana Kedokteran dan Profesi Dokter, Fakultas Kedokteran

Etiknurhidayati4@gmail.com

Diterima: 03-12-2019

Disetujui: $14-07-2020$

Diterbitkan: 01-08-2020

\section{PENDAHULUAN}

Kolesterol adalah komponen penting untuk proses kimiawi yang terjadi di tubuh manusia. Namun, jika kadar kolesterol tinggi di dalam darah maka akan mengakibatkan dampak negatif pada perlakuan dengan diet tinggi kolesterol dan pemberian dosis ekstrak kulit anggur yang berbeda-beda, yaitu dosis $100 \mathrm{mg} / 175 \mathrm{gbb}$, $250 \mathrm{mg} / 175 \mathrm{gbb}$ dan $500 \mathrm{mg} / 175 \mathrm{gbb}$. Pada akhir penelitian, yaitu hari ke- 30 , semua sampel diambil darahnya kemudian dilakukan uji MDA.

Hasil: Uji penelitian dengan Kruskal Wallis memperoleh hasil $p=0,035$ $(p<0,05)$ pada kelompok tikus yang diberikan ekstrak kulit anggur dengan dosis $100 \mathrm{mg} / 175 \mathrm{gbb}, 250 \mathrm{mg} / 175 \mathrm{gbb}$ dan $500 \mathrm{mg} / 175 \mathrm{gbb}$, sehingga menunjukkan kadar MDA lebih rendah signifikan dibanding dengan kontrol.

Simpulan: Pemberian ekstrak kulit buah anggur memiliki dampak penurunan MDA plasma pada tikus dengan diet tinggi kolesterol.

Kata kunci: Vitis vinifera L., antosianin, kolesterol, malondialdehid, MDA, kulit buah anggur

Cite Pasal Ini: Nurhidayati, E., Linawati, N.M., Sugiritama, I.W. 2020. Pemberian ekstrak kulit buah anggur (Vitis vinifera L.) mampu menurunkan kadar malondialdehid (MDA) plasma pada tikus dengan diet tinggi kolesterol. Intisari Sains Medis 11(2): 638-642. D0I: 10.15562/ism.v11i2.671

kesehatan, salah satunya adalah penyakit kardiovaskuler. Penyakit kardiovaskuler saat ini merupakan penyakit yang paling banyak menjadi penyebab kematian. Pada tahun 2012, tercatat 17 juta lebih 
kematian di seluruh dunia karena penyakit kardiovaskuler, dimana jantung koroner menduduki posisi tertinggi yaitu sebanyak $42 \%$ dimana dislipidemia merupakan faktor resiko tersering pada jantung coroner. ${ }^{1}$

Dislipidemia, suatu kelainan metabolisme lemak dan terjadi ketidakseimbangan fraksi lipid darah. Karakteristik gangguan ini yaitu peningkatan trigliserida (TG), low - density lipoprotein (LDL), kolesterol total, dan high - density lipoprotein (HDL) yang menurun. ${ }^{2}$

Radikal bebas yang meningkat pada kondisi dislipidemia mempengaruhi meningkatnya peroksidasi lipid yang dihasilkan. Diet tinggi kolesterol pada manusia meningkatkan stres oksidatif disertai dengan penurunan kadar antioksidan. ${ }^{3-5}$ Malondialdehyde (MDA) merupakan produk sekunder utama pada proses peroksidasi lipid karena lebih mutagenik dibanding aldehid lainnya dan dapat diukur pada keadaan ini. ${ }^{3-6}$

Antioksidan, senyawa dengan kemampuan protektif terhadap radikal bebas terkait penyakit kardiovaskuler. Mekanisme kerja dari antioksidan adalah mencegah terbentuknya senyawa baru radikal bebas atau memutus polimerasi untuk menstabilkan radikal bebas yang sudah terbentuk dan menjadi kurang reaktif. Kemampuan ini dikenal sebagai Chain-breaking-antioxidant ${ }^{7}$ dan free radical scavenger. Antosianin merupakan salah satu antioksidan, dimana menurut penelitian sebelumnya antosianin sendiri mampu menurunkan kadar LDL yang merupakan salah satu dari komponen kolesterol. ${ }^{8}$ Flavonoid, senyawa dengan kemampuan menghambat penyerapan kolesterol dan asam empedu pada usus halus, sehingga menurunkan kolesterol plasma. ${ }^{9}$

Kandungan antioksidan antosianin yang terdapat pada kulit buah anggur (Vitis vinifera L.) bisa menjadi salah satu pilihan alternatif. ${ }^{10-12}$ Keberadaan tanaman anggur sendiri di Indonesia, khususnya di Kecamatan Grokgak, Kabupaten Buleleng, Provinsi Bali, cukup mendukung. Dalam pembuatan white wine, kulit anggur merah tidak digunakan atau bisa dikatakan tidak mempengaruhi atau bahkan meningkatkan nilai ekonomis, sehingga dapat dipergunakan sebagai pemanfaatan kulit anggur (Vitis vinifera L.) sebagai terapi alternatif pencegahan pembentukan radikal bebas terkait penyakit kardiovaskuler. Oleh karena latar belakang tersebut, penelitian ini bertujuan untuk mengevaluasi efek ekstrak kulit anggur pada kadar MDA plasma.

\section{METODE}

\section{Bahan penelitian}

Bahan yang digunakan dalam penelitian ini disajikan dalam Tabel 1.

\section{Jenis penelitian}

Penelitian bersifat eksperimental dengan rancangan acak lengkap dan menggunakan desain post test control group only.

\section{Waktu dan lokasi penelitian}

Pembuatan ekstrak kulit anggur dilakukan di Laboratorium Analisis Pangan Fakultas Teknologi Pertanian, Universitas Udayana, Bali, Indonesia dan proses diet tinggi kolesterol serta pengujian ekstrak kulit buah anggur dilakukan di Laboratorium Histologi dan Laboratorium Biokimia Fakultas Kedokteran Universitas Udayana, Bali, Indonesia. Penelitian dilakukan pada bulan Juli sampai Agustus 2019.

\section{Variabel}

Variabel independen pada penelitian adalah ekstrak kulit anggur dan kadar MDA sebagai variabel terikat. Kulit anggur didapat dari limbah pabrik pembuat wine di Buleleng yang selanjutnya diekstrak dengan metode maserasi dan evaporasi. MDA diukur menggunakan spektrofotometer dalam satuan $\mathrm{ng} / \mathrm{mL}$. Variabel kontrol pada penelitian ini adalah diet tinggi kolesterol, usia, berat badan, dan lingkungan kandang tikus.

\section{Ekstraksi kulit anggur}

Kulit anggur setelah dikumpulkan dicuci dengan air mengalir dan dikeringkan. Setelah kering, kulit anggur dihancurkan sampai membentuk serbuk dan direndam dengan etanol $96 \%$ (perbandingan 1:7) dalam 3 hari lalu rendaman tersebut disaring (ekstrak 1). Maserasi ulang dilakukan pada residu dengan etanol 96\% (perbandingan 1:4) dalam 3 hari kemudian rendaman juga disaring (ekstrak 2). Ekstrak 1 dan 2 dicampurkan dan diuapkan menggunakan rotary evaporator sampai mendapatkan ekstrak kental kulit buah anggur.

\section{Subjek penelitian}

Tiga puluh tikus wistar digunakan sebagai subjek penelitian yang berusia 2-3 bulan dengan berat \pm 200 gram dan dalam kondisi sehat. Tikus wistar diacak ke dalam 5 kelompokyaitu 1 kelompok kontrol dan 4 kelompok intervensi dengan masing-masing terdapat 6 tikus dalam setiap kelompok. Selama 1 minggu tikus diaklimatisasi di tempat penelitian.

\section{Intervensi penelitian}

Diet tinggi kolesterol diberikan dengan kuning telur 10 gram, lemak kambing 20 gram, dan pakan standar 70 gram sebanyak 2 gram/hari dan diberikan secara adlibitum. Kelompok P1, P2, P3, dan P4 diberikan diet tinggi kolesterol. Ekstrak kulit anggur diberikan pada kelompok P2, P3, dan P4 dengan masing-masing dosis yaitu $100 \mathrm{mg} / 175 \mathrm{~g}$ bb (gram 
berat badan), $250 \mathrm{mg} / 175 \mathrm{~g} \mathrm{bb}, 500 \mathrm{mg} / 175 \mathrm{~g}$ bb. Kelompok kontrol hanya diberikan pakan standar. Kadar MDA diukur 30 hari setelah dilakukan intervensi.

\section{HASIL}

Kadar MDA yang didapatkan dari penelitian yang dilakukan tertera pada Tabel 2.

Selanjutnya data nilai MDA pada masingmasing kelompok diuji normalitasnya dengan menggunakan uji Shapiro-Wilk. Pada Tabel 3 menunjukkan bahwa dari kelima kelompok, terdapat satu kelompok (P3) yang tidak berdistribusi normal dengan nilai $\mathrm{p}<0,05$. Selanjutnya dilakukan uji homogenitas dengan menggunkan Levene Statistic. Hasil pada Tabel 4 memperlihatkan data homogen $(\mathrm{p}>0,05)$.

Dari hasil uji homogenitas selanjutnya uji komparabilitas dilakukan yang tujuannya adalah untuk melihat perbedaan rerata antara kelompok kelima kelompok perlakuan pada masing-masing kelompok post-test. Oleh karena data tidak terdistribusi normal, maka tidak bisa dilanjutkan dengan uji parametrik namun dapat dilakukan uji non-parametrik yaitu uji Kruskal Wallis. Hasil test non-parametrik dapat dilihat pada Tabel 5.

\section{PEMBAHASAN}

Pada kelompok tikus yang diberi diet tinggi kolesterol (P1) menunjukkan nilai kadar MDA plasma lebih tinggi dibandingkan dengan kelompok tikus yang diberi pakan standar (kontrol). Pada Tabel 2 didapatkan bahwa Kelompok tikus dengan diet tinggi kolestrol dan ekstrak kulit anggur dengan dosis $100 \mathrm{mg} / 175 \mathrm{gbb}$ (P2) menunjukkan nilai kadar MDA plasma lebih rendah (signifikan) dibandingkan dengan kelompok tikus yang diberi pakan tinggi kolesterol (P1). Kelompok tikus yang diberi diet tinggi kolestrol dan ekstrak kulit anggur dengan dosis $250 \mathrm{mg} / 175 \mathrm{gbb}$ (P3) menunjukkan nilai kadar MDA plasma lebih rendah (signifikan) dibandingkan dengan kelompok tikus yang diberi pakan tinggi kolesterol (P1). Kelompok tikus yang diberi diet tinggi kolestrol dan ekstrak kulit anggur dengan dosis 500 mg/ 175 gbb (P4) menunjukkan nilai kadar MDA plasma lebih rendah (signifikan) dibandingkan dengan kelompok tikus yang diberi pakan tinggi kolesterol (P1). Hal ini menunjukkan bahwa peningkatan MDA yang ditimbulkan oleh pemberian diet tinggi kolesterol dapat diturunkan dengan pemberian ekstrak kulit buah anggur. Penelitian ini sejalan dengan penelitian pada kelinci memberikan hasil peningkatan MDA pada subjek yang diberikan diet tinggi kolesterol, peningkatan MDA ini merupakan pertanda dari stress oksidatif. ${ }^{13,14}$

Ekstrak kulit anggur yang diberikan sebagai usaha meningkatkan antioksidan plasma dengan kandungan polifenol seperti flavonol, antosianon, asam fenol, dan proantosianidin pada buah anggur. $^{15,16}$ Pada penelian Narendhirakannan mengenai aktivitas antioksidan kulit anggur didapatkan senyawa fitokimia seperti flavonoid, alkaloid, dan saponin. ${ }^{17}$ Antioksidan mampu memperlambat/menghambat proses dari oksidasi. Oksidasi merupakan reaksi kimia yang melibatkan

Tabel 1 Bahan penelitian

\begin{tabular}{lll}
\hline No & Nama bahan & Kegunaan \\
\hline 1 & Etanol 96\% & Pelarut ekstraksi kulit buah anggur \\
2 & Kulit buah anggur & Bahan uji coba \\
3 & Lemak kambing & Bahan diet tinggi kolesterol \\
4 & Kuning telur & Bahan diet tinggi kolesterol \\
5 & Pakan standar (BR2) & Bahan pakan tikus kontrol dan bahan diet tinggi kolesterol \\
6 & Tikus wistar & Hewan uji coba \\
7 & Kapas/tisu & Pembersih alat \\
\hline
\end{tabular}

Tabel 2 MDA plasma tikus setelah mendapat perlakuan dengan ekstrak kulit buah anggur

\begin{tabular}{lcccc}
\hline Kelompok & $\mathbf{n}$ & Rerata \pm SD & Minimun & Maximum \\
\hline Kontrol & 5 & $1,85 \pm 0,32$ & 1,40 & 2,24 \\
P1 & 5 & $2,26 \pm 0,20$ & 1,96 & 2,46 \\
P2 & 5 & $1,83 \pm 0,13$ & 1,68 & 2,02 \\
P3 & 5 & $1,93 \pm 0,48$ & 1,66 & 2,80 \\
P4 & 5 & $1,60 \pm 0,20$ & 1,26 & 1,78 \\
\hline
\end{tabular}


Tabel 3 Uji Normalitas

\begin{tabular}{lc}
\hline Uji Normalitas (Kadar MDA) & Nilai p \\
\hline Kontrol & $0,968^{*}$ \\
P1 & $0,566^{*}$ \\
P2 & $0,576^{*}$ \\
P3 & 0,003 \\
P4 & $0,148^{*}$ \\
\hline
\end{tabular}

"Data berdistribusi normal jika $\mathrm{p}>0,05$

Tabel 4 Uji Homogenitas

\begin{tabular}{lc}
\hline Levene statistic & Nilai $\mathbf{p}$ \\
1,539 & $0,229^{*}$
\end{tabular}

Tabel 5 Hasil analisis Kruskal Wallis rerata nilai MDA plasma tikus wistar

\begin{tabular}{lccc}
\hline Kelompok & $\mathbf{n}$ & Rata-rata \pm SD $(\mathbf{n g} / \mathbf{m L})$ & Nilai $\mathbf{p}$ \\
\hline Kontrol & 5 & $1,85 \pm 0,32$ & \\
P1 & 5 & $2,26 \pm 0,20^{\mathrm{a}}$ & \\
P2 & 5 & $1,83 \pm 0,13^{\mathrm{b}}$ & $0,035^{*}$ \\
P3 & 5 & $1,93 \pm 0,48^{\mathrm{b}}$ & \\
P4 & 5 & $1,60 \pm 0,20^{\mathrm{b}}$ & \\
\hline
\end{tabular}

Keterangan:

*signifikan bila $\mathrm{p}<0,05$

adibandingkan dengan kontrol

bdibandingkan dengan P1 tidak memeriksa kandungan fitokimia dari ekstrak kulit anggur yang bersifat sebagai antioksidan, penelitian ini hanya memeriksa kadar MDA pada plasma darah tikus. Perlu dilakukan penelitian lebih lanjut mengenai dosis yang optimal pemberian ekstrak kulit buah anggur pada manusia yang dapat mencegah terjadinya stress oksidatif, efek samping pemberian ekstrak kulit buah anggur, dan uji fitokimia (antioksidan) pada ekstrak kulit buah anggur untuk melihat kandungan spesifik yang memegang peranan penting atau utama dalam menurunkan kadar MDA.

\section{SIMPULAN}

Berdasarkan hasil dari penelitian pemberian ekstrak kulit buah anggur pada tikus yang diberikan diet tinggi kolesterol didapatkan simpulan yaitu pemberian ekstrak kulit buah anggur pada tikus yang diberikan diet tinggi kolesterol dengan dosis $100 \mathrm{mg} / 175 \mathrm{~g} / \mathrm{kgBB}$ mampu menurunkan kadar MDA plasma secara signifikan.

\section{PERSETUJUAN ETIK}

Penelitian ini telah disetujui oleh Komisi Etik Penelitian Fakultas Kedokteran Universitas Udayana/Rumah Sakit Umum Pusat Sanglah Denpasar dengan nomor: 602/UN14.2.2.VII.14/ LP/2019.

pengikatan dari oksigen, pelepasan dari hidrogen, ataupun pelepasan dari elektron. ${ }^{15-18}$ Hasil penelitian ini sesuai dengan hasil penelitian yang dilakukan Jawi yaitu mengenai pengaruh ubi jalar ungu pada stress oksidatif mencit menghasilkan efek preventif pada stress oksidatif. Penurunan kadar MDA terlihat setelah administrasi ubi jalar ungu. ${ }^{14}$ Penelitian ini sejalan dengan studi Wongsodipuro yaitu mencit terinduksi $\mathrm{H}_{2} \mathrm{O}_{2} 3 \%$ memperlihatkan adanya penurunkan MDA pada eritrosit Ghost Cell yang diberikan ekstrak anggur dibandingkan mencit yang diberikan normal saline dan hidrogen peroksida $3 \% .{ }^{19}$ Hasil penelitian ini juga sesuai dengan studi Siswanto yang menunjukan administrasi ekstrak anggur dengan dosis $0,5 \mathrm{ml} /$ hari signifikan menurunkan kadar aspartat aminotransferase pada mencit yang diinduksi latihan fisik berlebih. ${ }^{20}$

Kadar peroksidasi lipid mempengaruhi tingginya MDA, secara tidak langsung memperlihatkan jumlah radikal bebas yang tinggi di dalam tubuh. $^{21}$ Kelemahan penelitian ini ialah tidak diketahuinya antioksidan mana yang memegang peranan utama dalam menurunkan kadar MDA plasma. MDA merupakan biomarker yang secara luas digunakan untuk mengukur atau menilai stress oksidatif di bidang biomedis. Pada penelitian ini

\section{KONTRIBUSI PENULIS}

Seluruh penulis yang memberikan kontribusi sejak pemilihan ide penelitian, penyusunan proposal, pengambilan data, pengolahan data, persiapan manuskrip, dan publikasi hasil penelitian.

\section{PENDANAAN}

Seluruh pendanaan pada penelitian ini berasal dari dana pribadi penulis.

\section{KONFLIK KEPENTINGAN}

Tidak terdapat konflik kepentingan terkait publikasi hasil penelitian ini.

\section{DAFTAR PUSTAKA}

1. Kementrian Kesehatan Republik Indonesia. Penyakit Jantung Penyebab Kematian Tertinggi, Kemenkes Ingatkan CERDIK. Jakarta: Kementrian Kesehatan Republik Indonesia. 2017.

2. Kumar V, Abbas A, Aster J. Robbins Basic Pathology. Edisi kesembilan. Canada: Elsevier. 2013:335-43.

3. Badan Penelitian dan Pengembangan Kesehatan. Riset Kesehatan Dasar (Riskesdas) 2013. Jakarta: Kementrian Kesehatan Republik Indonesia. 2013. 
4. Ayala A, Munoz MF, Arguelles S. Lipid peroxidation: production, metabolism and signaling mechanism of malondialdehyde and 4- hydroxy-2-nonenal. Oxid Med Cell Longev. 2014; 112: 21-8.

5. Artha IMJR, Bhargah A, Dharmawan NK, Pande UW, Triyana KA, Mahariski PA, Yuwono J, Bhargah V, Prabawa IPY, Manuaba IBAP, Rina IK. High level of individual lipid profile and lipid ratio as a predictive marker of poor glycemic control in type-2 diabetes mellitus. Vasc Health Risk Manag. 2019 Jun 5;15:149-157. doi: 10.2147/VHRM.S209830. PMID: 31239693; PMCID: PMC6560183.

6. Yang RL, Shi YHS, Li W, Le GW. Increasing oxidative stress with progressive hyperlipidemia in human: relation between malondialdehyde and atherogenic index. J Clin Biochem Nutr. 2008;43(3):154-8.

7. Winarsi. Antioksidan Alami dan Radikal Bebas. Yogyakarta: Kanisius. 2007:189-90.

8. Rukmanasari R. Efek ekstrak kulit terong ungu (Solanum melongena L.) terhadap kadar LDL dan HDL darah tikus putih. Surakarta: Universitas Sebelas Maret. 2010.

9. Zeka K, Ruparelia K, Arroo RJR, Budriesi R, Micucci M. Flavonoids and Their Metabolites: Prevention in Cardiovascular Disease and Diabetes. Diseases. 2017;5(3):1-102.

10. Utami MA, Sholika M. Vitis vinifera L.. Jakarta: Universitas Indonesia Departemen Farmasi. 2011.

11. Ozden M, Damire U, Kahraman A. Effects of proline on antioxidant system in leaves of grapevine (Vitis vinifera L.) exposed to oxidative stress by $\mathrm{H} 2 \mathrm{O} 2$. Scientia Horticulturae. 2009;119(2):163-168

12. Safaei N, Babaei H, Azarfarin R, Jodati AR, Yaghoubi A, Sheikhalizadeh MA. Comparative Effect of Grape Seed Extract (Vitis Vinivera) and Ascorbic Acid in Oxidative Stress Induced by On-pump Coronary Artery Bypass Surgery. Annals of Cardiac Abaesthesia. 2017;20(1):1-39.

13. Jawi IM, Budiasa K. Ekstrak air ubi jalar ungu menurunkan total kolesterol serta meningkatkan total antioksidan darah kelinci. Jurnal Veteriner. 2011;12(2):120-125.
14. Jawi IM, Suprapta DN, Subawa AAN. Ubi Jalar Ungu Menurunkan Kadar MDA dalam Darah dan Hati Mencit setelah Aktivitas fisik Maksimal. Jurnal Veteriner. 2008;9(2):65-71.

15. Shi J, Yu J, Pohorly JE, Kakuda Y. Polyphenolics in grape seeds-biochemistry and functionality. J Med Food. 2003;6:291-299.

16. Xia EQ, Deng GF, Guo YJ, Li HB. Biological Activities of Polyphenols from Grape. Int J of Mol Sci. 2010;11:622-646.

17. Narendhirakannan RT, Nirmala JG. In Vitro Antioxidant And Antimicrobial Activities Of Grapes (Vitis Vinifera L.) Seed And Skin Extracts - Muscat Variety. Int J Pharm Sci. 2011;3(4):242-249.

18. Jayaprakasha GK, Singh RP, Sakariah KK. Antioxidant activity of Grape Seed (Vitis vinera) Extracts on Peroxidantion Models In Vitro. Food chem. 2001;73(3):285-290.

19. Wongsodipuro A. Pemberian Ekstrak Anggur (Vitis vinera) Menurunkan Kadar MDA pada Eritrosit Ghost Cell Tikus yang Diinduksi Hidrogen Peroksida 3\% (Tesis). Denpasar: Program Pascasarjana, Program Studi Magister Kedokteran Anti Penuaan, Universitas Udayana. 2010.

20. Siswanto FM, Suryawan IW, Wirawan TF, Rochman F, Pangkahila JA. Ekstrak Buah Anggur Menurunkan Kadar Aspartate Transaminase Darah Mencit dengan Aktivitas Fisik Berlebih. Indonesia Mediscus Veterinus. 2014;3(3):192-199.

21. Halliwell B, Gutteridge JMC. The definition and measurement of antioxidants in biological systems. Free Radic Biol Med. 1995;18:125-126.

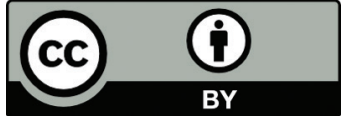

This work is licensed under a Creative Commons Attribution 